\title{
Cryptosporidium spp. in bursa of Fabricius of broiler chickens from Uruguay
}

\author{
Cryptosporidium spp. em bursa de Fabrícius de frangos de corte no Uruguai
}

\author{
Susana Casanova ${ }^{\mathrm{I}}$ José Manuel Verdes $^{\mathrm{II}}$ Kosuke Okada ${ }^{\mathrm{III}}$
}

\section{- NOTE -}

\begin{abstract}
The presence of Cryptosporidium spp. was detected in broiler chickens of 32-40 days of age, colonizing the bursa of Fabricius. The histologic study with haematoxylin and eosin staining was done on specimens of trachea, complete intestinal tract and bursa. Samples of intestinal content were also studied using Kinyoun staining technique. All birds with signs of illness were positive to the presence of parasite, showing a hypertrophic bursa of Fabricius, filled with caseous content. The bursal epithelial cells were full of different developmental stages of Cryptosporidium spp. This note describing the presence of Cryptosporidium spp. in industrial flocks of broiler chickens, is the first report of this parasite in Uruguay.
\end{abstract}

Key words: Cryptosporidium spp., broiler chickens, bursa of Fabricius.

\section{RESUMO}

A presença de Cryptosporidium spp. foi detectada em frangos de corte de 32-40 dias de idade, colonizando a bursa de Fabrícius. O estudo histológico com hematoxilina e eosina foi feito em amostras de traqueia, trato intestinal completo e bursa. As amostras de conteúdo intestinal também foram estudadas utilizando a técnica de coloração de Kinyoun. Todas as aves com sinais de doença foram positivas para a presença do parasita, mostrando uma bursa de Fabrícius hipertrófica com grande quantidade de conteúdo caseoso. As células epiteliais bursais estavam repletas de diferentes estágios de desenvolvimento de Cryptosporidium spp. Esta nota, que descreve a presença de Cryptosporidium spp. em lotes industriais de frangos de corte, é o primeiro relato deste parasita no Uruguai.

Palavras-chave: Cryptosporidium spp., frangos de corte, bursa de Fabrícius.
Cryptosporidium is a genus of protozoan parasites that belongs to the Order Eucoccidiorida, Suborder Eimeriorida, family Crysptosporidiidae. In birds, cryptosporidiosis is one of the most prevalent parasitic infections in more than 30 domestic and wild bird species, and can be found in the digestive and respiratory tracts and in the bursa of Fabricius of affected animals. The three most important pathogenic species in birds are: Cryptosporidium baileyi, $C$. meleagridis, and $\boldsymbol{C}$. galli (GOODWIN, 1989; SRÉTER \& VARGA, 2000; MENG et al., 2011); in broiler chickens and laying hens, cryptosporidiosis was mainly associated with $\boldsymbol{C}$. baileyi (GOODWIN, 1989; SRÉTER \& VARGA, 2000; TRAMPEL et al., 2000), and some Cryptosporidia-like $\boldsymbol{C}$. meleagridis- are potentially zoonotic, thus being important in human public health (CHENG et al., 2002; MENG et al., 2011).

Clinical cryptosporidiosis in birds is characterized by different degrees of respiratory and digestive signs, and might develop as a consequence of stress under high fed conversion schedule managements, or as an ancillary disease of another primary illness -i.e., several immunodeficiency conditions- (SRÉTER \& VARGA, 2000); in broiler chickens, $\boldsymbol{C}$. baileyi plays an important role in the pathogenesis of respiratory diseases, and economic losses can be unexpectedly high (SRÉTER \& VARGA, 2000). The histological lesions caused

'Poultry Pathology and Production Department, Veterinary School, Universidad de la República (UdelaR), Av. A. Lasplaces, 1550, 1620, CP 11600, Montevideo, Uruguay. E-mail: scasanovaesposito@gmail.com. Corresponding author.

${ }^{\Pi}$ Molecular and Cellular Biology (Biophysics), and Pathology Departments, Faculty of Veterinary, UdelaR, Montevideo, Uruguay.

IIISenior Volunteer of Japan International Cooperation Agency (JICA), Montevideo, Uruguay. 
by $\boldsymbol{C}$. baileyi in the bursa of Fabricius may inhibit the development of humoral immunity, which may have a negative effect on the development of defense mechanisms after vaccination, rendering chickens vulnerable to other pathogens (SRÉTER \& VARGA, 2000). The examination of formalinfixed tissues with haematoxylin and eosin staining has been the diagnostic method of choice, showing cryptosporidians as $2.0-7.5 \mu \mathrm{m}$ basophilic bodies within the brush border of the epithelial cells (SRÉTER \& VARGA, 2000).

Cryptosporidium baileyi has been mentioned infecting turkeys and quails with lesions in the respiratory and digestive tracts and in bursa of Fabricius (DHILLON, 1981). C. meleagridis was reported in turkeys, while $\boldsymbol{C}$. galli was found in wild birds and chickens. This disease is recognized as worldwide-distributed, but until now studies in South America, particularly in industrial flocks, are still rather scarce. It has been reported in Argentina (HERRERO-LOYOLA et al., 1992) and Venezuela (SURUMAY et al., 1996), and more recently Cryptosporidium spp. were identified from smears of intestine, bursa of Fabricius and trachea of healthy chickens in Brazil (JACOBSEN et al., 2006).

The aim of this note is to report the presence of developmental stages of Cryptosporidium spp. in epithelium of bursa of Fabricius of broiler chickens from industrial flocks in Uruguay.

The samples were obtained at four poultry farms from the 6th and 12th zones in Canelones Department, southern Uruguay. About $80 \%$ of the total poultry meat production of Uruguay (ca. 35:000.000 broilers per year) comes from this area. The vaccination schedule of the studied poultry population consists of recombinant vaccination against Marek disease, infectious bursal disease plus infectious bronchitis in spray in hatchery, at day one of birth. During the rearing period, each flock received a second bronchitis vaccine by spray. The biosecurity of the farms was the usual for the poultry industry in Uruguay. The water was chlorinated, and food was supplied to the farm in bulk truck. General management and bird densities were according the conventional productive conditions in Uruguay.

Farm \# 1: about 50.000 broilers with 38 days of age divided in 6 different houses. They presented uneven development with no signs of illness. Farm \# 2: Single flock of 12.000 broilers aged 32 days, uneven development with no other signs. Farm \# 3: Single flock of 10.000 broilers aged 40 days lodged in one house with respiratory signs. Farm \# 4: A total of 30.000 broilers aged 39 days lodged in 3 houses, showing animals with respiratory signs in all of houses. Three animals among the least developed birds in each farm were sampled.

Post-morten examination of selected animals was carried out, and tissue samples from trachea, duodenum, caecum, last portion of intestine, bursa of Fabricius were taken and fixed in $10 \%$ formalin, dehydrated in graded alcohol, cleared in xylene, embedded in paraffin, sectioned at $5 \mu \mathrm{m}$. Eight to ten slides of each tissue sample were stained with $\mathrm{H} \& \mathrm{E}$ for histopathologic evaluation. Intestinal content from the same carcasses was collected in sterile flasks, refrigerated, and transported to the laboratory where direct smears obtained without sedimentation were stained following the Kinyoun technique (LEMOS et al., 2012), and evaluated with objective immersion lens (1000x).

At post-morten examination all chicken samples from farms \# 3 and \# 4 showed an enlargement of bursa of Fabricius, with abundant mucous luminal content. No other gross lesions were found at necropsy in these carcasses, as also in animals from farms \# 1 and \# 2.

The histopathological evaluation of all the samples from different organs were processed.

All samples obtained from bursas of animals of farms \# 3 (3/3) and \# 4 (3/3) were positive to the presence of Cryptosporidium spp.

Histopathological findings in study cases from these farms confirmed the bursitis identified at necropsy, showing hyperplasia of bursal epithelial cells, with various life-cycle stages of Cryptosporidia parasitizing the microvillus border. Large number of spherical to ovoid pleomorphic and basophilic bodies were found in epithelial cells of the bursa, which are characteristic of Cryptosporidium infection. The parasites were particularly abundant on the epithelium surface of the bursa of Fabricius in three chickens (Figure 1). The size of the parasites was from 1 to $4 \mu \mathrm{m}$, and based on size and basophilia we identified at least 2 different life-cycle stages on the microvillus border: trophozoites (small basophilic bodies) and macrogametocytes (larger and less basophilic) (Figure 1). Microscopical evaluation of the smears of intestinal content from all necropsied birds with Kinyoun staining (0/12) were negative to the presence of Cryptosporidium spp. oocytes.

Our results with conventional histopathology demonstrated the presence of different developmental stages of Cryptosporidium spp. parasitizing epithelial cells of bursa de Fabricius only in the case of chickens with respiratory signs. This finding was in agreement with the bursitis 


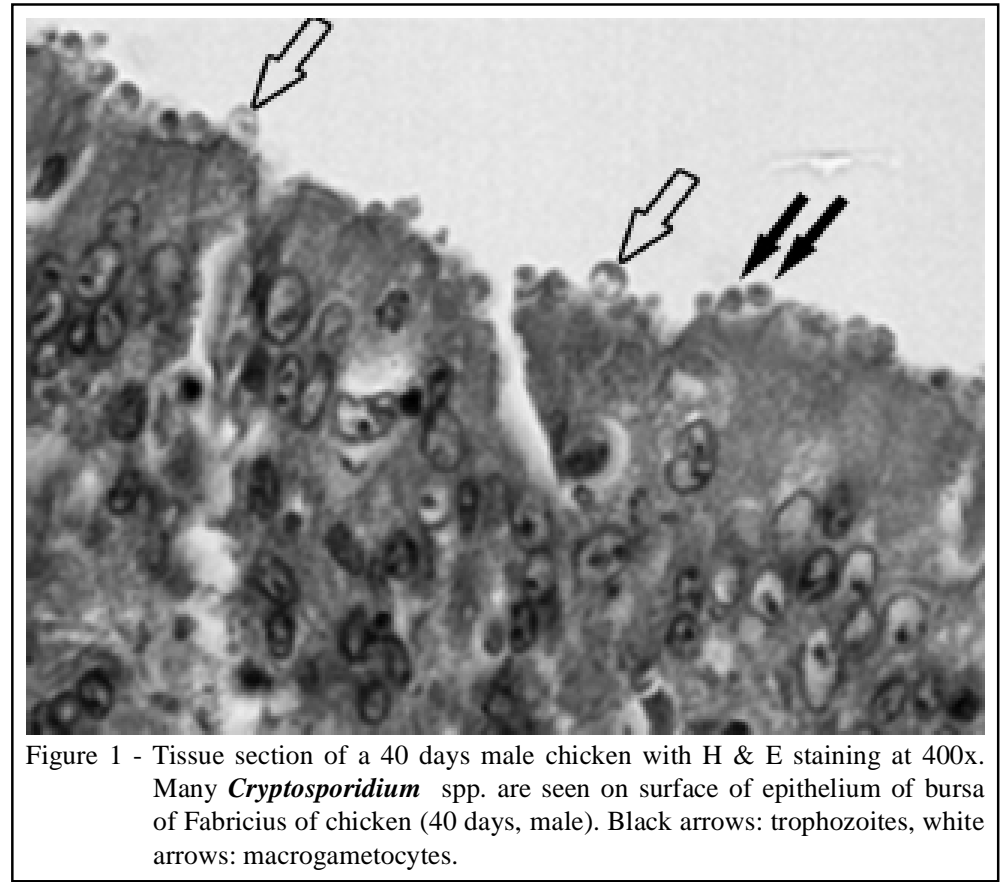

and bursal hypertrophy observed during postmorten examination. No other specific macroscopic or microscopic lesions were found. Differential diagnosis with Infectious Bursal Disease caused by classical or hypervirulent strains, was established in our cases based on previous vaccination history and low mortality, together with the absence of other typical macroscopic findings like oedematous, haemorrhagic or atrophic bursae, haemorrhagic carcass muscles, nephritis, and/or abundant intestinal mucous content (TESSARI et al., 2001; SAG, 2014).

According to GOODWIN (1989), the haematoxylin and eosin-staining of tissue sections is a sensitive method for the identification of the parasites. Additionally, the specificity of parasite location in epithelial bursal cells, suggests that $\boldsymbol{C}$. baileyi is the species involved in affected animals. Previous reports indicate that it is the best location to find $\boldsymbol{C}$. bailey in broiler chickens (FLETCHER et al., 1975; GOODWIN, 1989; SURUMAY et al., 1996; JACOBSEN et al., 2006; MC DOUGALD et al., 2008).

In our case, intestinal content smears with Kinyoun technique without centrifugal sedimentation concentration method, was not able to identify Cryptosporidia oocysts in intestinal content smears. Previous centrifugation of intestinal content samples would improve diagnosis, minimizing false negative results (LEMOS et al., 2012).

This first report from Uruguay in broiler chickens indicates that more research on the occurrence of Cryptosporidium is necessary, including surveys on breeders and layers to assess its actual incidence, the economic relevance and the potential public health significance of some of these potential zoonotic parasites.

\section{ETHICS COMMITTEE AND BIOSECURITY}

CEUAFVET-PI 31 - Exp. 111130-002085-13.

\section{ACKNOWLEDGEMENTS}

This work was supported by Comisión de Investigación y Desarrollo Científico (Veterinary School, Universidad de la República, CIDEC-FVET-UdelaR, Uruguay), and Japan International Cooperation Agency (JICA, Japan).

\section{REFERENCES}

CHEN, X.-M. et al. Cryptosporidiosis. New England Journal of Medicine, v.346, n.22, p.1723-1731, 2002. Available from: <http:// www.nejm.org/doi/full/10.1056/NEJMra013170>. Accessed: Jul. 24, 2014. doi: 10.1056/NEJMra013170.

DHILLON, A.S. et al. Respiratory Cryptosporidiosis in broiler chickens. Avian Diseases, v.25, n.3, p.747-751, 1981. Available from: 〈http://www.jstor.org/stable/1590007〉. Accessed: Jul. 24, 2014. doi: $10.2307 / 1590007$.

FLETCHER, O.J. et al. Cryptosporidiosis of the bursa of Fabricius of chickens. Avian Diseases, v.19, n.3, p. 630-639, 1975. Available from: 〈http://www.jstor.org/stable/1589092>. Accessed: Jul. 24, 2014. doi: 10.2307/1589092.

GOODWIN, M.A. Crytosporidiosis in birds. A review. Avian Pathology, v.18, n.3, p.365-384, 1989. Available from: <http:// www.tandfonline.com/doi/abs/10.1080/03079458908418612\#. 
U9GEbNySxmM>. Accessed: Jul. 24, 2014 . doi: 10.1080/03079458908418612.

HERRERO-LOYOLA, M.A. et al. Descripción de casos de crisptosporidiosis en aves. Revista de Medicina Veterinaria, v.73, n.4, p.188-190, 1992. Available from: <http://ppct.caicyt. gov.ar/index.php/rmv/index>. Accessed: Jul. 24, 2014.

JACOBSEN, G. et al. Cryptosporidium sp. em intestinos, bursa de Fabricius e traquéia de frangos (Gallus gallus). Ciência Rural, v.36, n.2, p.682-684, 2006. Available from: <http://dx.doi. org/10.1590/S0103-84782006000200053>. Accessed: Jul. 24, 2014. doi: 10.1590/S0103-84782006000200053.

MC DOUGALD, L.R. Protozoal infections. In: SAIF, Y.D. (Ed.in chief). Diseases of poultry. 12.ed. Iowa: Blackwell, 2008. p.1085-1091.

LEMOS, F.O. et al. Cryptosporidium species screening using Kinyoun technique in domestic cats with diarrhea. Journal of Feline Medicine and Surgery, v.14, n.2, p.113-117, 2012 Available from: <http://jfm.sagepub.com/content/14/2/113.full>. Accessed: Jul. 24, 2014. doi: 10.1177/1098612X11429221.

MENG, Q. et al. Cryptosporidium spp. in pet birds: Genetic diversity and potential public health significance. Experimental Parasitology, v.128, n.4, p.336-340, 2011. Available from: <http:// www.sciencedirect.com/science/article/pii/S0014489411001421>. Accessed: Jul. 24, 2014. doi: 10.1016/j.exppara.2011.04.003.
SAG (SERVICIO AGRÍCOLA Y GANADERO). Enfermedad de Gumboro. Chile: Servicio Agrícola y Ganadero -Sanidad Animal, Ministerio de Agricultura, Gobierno de Chile, 2014. p.1-2. Available from: <http://www.sag.cl/sites/default/files/ enfermedad_Gumboro.pdf >. Accessed: Feb. 06, 2014.

SRÉTER, T.; VARGA, I. Cryptosporidiosis in birds - A review. Veterinary Parasitology, v.87, n.4, p.261-279, 2000. Available from: <http://www.sciencedirect.com/science/article/pii/ S0304401799001788>. Accessed: Jul. 24, 2014. doi: 10.1016/ S0304-4017(99)00178-8.

SURUMAY, Q. et al. Cryptosporidium baileyi en la bolsa de Fabricio de pollos de engorde, Región Centro-Costera de Venezuela. Veterinaria Tropical, v.21, n.1, p.103-107, 1996. Available from: <http://sian.inia.gob.ve/repositorio/revistas_ci/ VeterinariaTropical/vt2101/texto/qsurumay.htm>. Accessed: Oct. 17,2013

TESSARI, E.N.C. et al. Ocorrência da doença de Gumboro em aves de postura causadas por cepas hipervirulentas. Arquivos do Instituto Biológico, v.68, n.1, p.115-117, 2001. Available from: <http://www.biologico.sp.gov.br/docs/arq/V68_1/21.pdf>. Accessed: Jul. 24, 2014.

TRAMPEL, D.W. et al. Urinary tract cryptosporidiosis in commercial laying hens (case report). Avian Diseases, v.44, n.2, p.479-484, 2000. Available from: <http://www.jstor.org/ stable/1592566>. Accessed: Jul. 24, 2014. doi: 10.2307/1592566. 